九州大学学術情報リポジトリ

Kyushu University Institutional Repository

\title{
Preliminary chromosome studies on Hippeastrum species from Vietnam
}

Hang, Tran Thi Minh

Department of Horticulture, Faculty of Agronomy, Vietnam National University of Agriculture

Phuong, Pham Thi Minh

Department of Horticulture, Faculty of Agronomy, Vietnam National University of Agriculture

Dung, Trinh Thi Mai

Department of Horticulture, Faculty of Agronomy, Vietnam National University of Agriculture

Mi yaj ima, Ikuo

Institute of Tropical Agriculture, Kyushu University

https://doi.org/10.5109/1526299

出版情報 : 九州大学大学院農学研究院紀要. 60 (1)，pp.51-55，2015-02-27. Faculty of Agriculture， Kyushu University

バージョン :

権利関係 : 


\title{
Preliminary chromosome studies on Hippeastrum species from Vietnam
}

\author{
Tran Thi Minh HANG ${ }^{1 *}$, Pham Thi Minh PHUONG ${ }^{1}$, \\ Trinh Thi Mai DUNG ${ }^{1}$ and Ikuo MIYAJIMA ${ }^{2}$ \\ Institute of Tropical Agriculture, Kyushu University, \\ Fukuoka 812 - 8581, Japan \\ (Received October 24, 2014 and accepted November 14, 2014)
}

\begin{abstract}
Hippeastrum plants collected from different provinces of Vietnam and grown in the greenhouse at the Vietnam National University of Agriculture exhibit diversity in several morphological characteristics, especially in flower size and color. In order to understand the karyotypes and the phylogenesis of Hippeastrum species in Vietnam, somatic chromosome counts and karyotyping were performed for 97 Hippeastrum accessions. Chromosome counts showed that most (62 of 97 accessions, or 63.9\%) Hippeastrum accessions in this collection are diploid with somatic chromosome number $2 n=2 \mathrm{x}=22$. Three accessions, or $3.1 \%$, are triploid $(2 n=3 \mathrm{x}=33)$. This collection includes 32 tetraploids, or $33 \%$, that have chromosome number $2 n=4 \mathrm{x}=44$. The karyotypes of three Hippeastrum species in Vietnam, including $H . \mathrm{x}$ 'Johnsonii', $H$. puniceum, and $H$. reticulatum var. striatifolia Herb. were analyzed. Karyotype variation among these three species included differences in chromosome lengths, long arm to short arm ratios, centromere positions, and chromosomes types. These species carry one to three unequal pair(s) of chromosomes in their chromosome complements. The results of this research will be useful for identification and classification of Hippeastrum species and subspecies.
\end{abstract}

Key words: chromosome, germplasm, Hippeastrum, karyotype analysis

\section{INTRODUCTION}

Hippeastrum species are ornamental bulb-bearing flowering plants that belonging to the genus Hippeastrum in the Hippeastreae tribe of the Amaryllidaceae family. According to Okubo (1993), they are native to Central and South America, and therefore adapt easily to tropical and subtropical regions. More than 70 Hippeastrum species in tropical and subtropical regions of South America have been reported (Poggio et al., 2007).

In Vietnam, Hippeastrum plants are widely grown in many home gardens. They were imported to Vietnam long ago and have become distributed throughout the country. Due to their easy cultivation and vegetative propagation, many Hippeastrum plants currently growing in Vietnam are generally local cultivars that have been propagated mainly by home or commercial growers for many years. Due to increasing demand for Hippeastrum in Vietnam, a number of new Hippeastrum varieties have been imported and introduced for production. However, the main limitations of using imported seeds are their limited supply and expense. Therefore, is has become necessary to perform Hippeastrum breeding in Vietnam in order to satisfy the demand for new cultivars for domestic production. Researchers at the Vietnam National University of Agriculture have collected 97 Vietnamese Hippeastrum accessions from all over the country to a develop germplasm collection to use for selecting and breeding improved varieties. To effectively

\footnotetext{
1 Department of Horticulture, Faculty of Agronomy, Vietnam National University of Agriculture, Gialam, Hanoi, Vietnam;

2 Institute of Tropical Agriculture, Kyushu University, Fukuoka 812-8581, Japan

* Corresponding author (E-mail: ttmhang@vnua.edu.vn)
}

exploit this germplasm collection, it will be necessary to evaluate the genetic diversity of its accessions, including by karyotype analysis.

The genus Hippeastrum contains taxa with a variety of chromosome numbers and ploidy levels that affect the utility of each taxon for breeding purposes (Williams and Dudley, 1984). Therefore, many chromosome studies have been carried out previously on Hippeastrum species (Baldwin and Speese, 1947; Guha, 1979; Arroyo, 1982; Naranjo and Poggio, 1988; Shafiq and Vahidy, 1998). These researchers have reported the basic chromosome number of Hippeastrum species as $\mathrm{x}=11$, with ploidy levels ranging from diploid to hexaploid. Interestingly, Arroyo (1982) discovered aneuploid Hippeastrum species. Although Hippeastrum cultivation has long been popular in Vietnam, as yet there have been no studies on the regional genetic diversity and or karyotypes of the genus. This study aims to discover the karyotype diversity of Hippeastrum species in Vietnam with an initial focus on diploid species.

\section{MATERIALS AND METHODS}

\section{Plant materials}

A total of 97 Hippeastrum accessions have been collected from various provinces in Vietnam since 2010 and grown in the greenhouse of Agronomy Faculty at the Vietnam National University of Agriculture. Chromosome numbers were evaluated in all of these accessions. Chromosome measurement and karyotyping were carried out on individual plants from three accessions (H141, H142, and H128) previously identified as diploid accessions that belong to the species $H$. x 'Johnsonii', $H$. puniceum, and $H$. reticulatum var. striatifolia Herb (Phuong et al., 2014). 


\section{Somatic chromosome preparation}

Five young root tips of accessions H141, H142, and H128 were collected and pretreated with $0.05 \%$ colchicine at $20^{\circ} \mathrm{C}$ for $3 \mathrm{~h}$. Root tips were then fixed in the Carnoy's solution (1 part acetic acid, 3 parts ethanol, $\mathrm{v} / \mathrm{v}$ ) for $24 \mathrm{~h}$. Fixed root tips were then hydrolyzed in $1 \mathrm{~N} \mathrm{HCl}$ at $60^{\circ} \mathrm{C}$ for $6 \mathrm{~min}$ and stained with leucobasic fuchsine at $10^{\circ} \mathrm{C}$ for $6 \mathrm{~h}$.

\section{Chromosome observation}

Treated root tips were squashed in $45 \%$ acetic acid and observed under the microscope. Somatic chromosomes were counted and lengths of the long and short arms of each chromosome were measured.

\section{Karyotyping}

Karyotypes were constructed from a photograph of the best chromosome spread for each accession. Individual chromosomes were excised from the photograph, then arranged and adhered onto a sheet of paper after classifying each chromosome according to its length and centromere position. The chromosome pairs of each of these three diploid accessions (H141, H142, and H128) were numbered from I to XI based on the lengths of each chromosome from longest to shortest. Chromosome pairs arranged in the karyoidiograms were divided into three groups following Baldwin and Speese (1947): group A (including chromosomes with the shortest short arm), group B (including chromosomes with a longer short arm), and group C (including chromosomes that are approximately isobrachial). Chromosome arm ratios were calculated as the long arm length divided by the short arm length. The centromeric index (CI) for each chromosome was calculated by dividing the long arm length by the total chromosome length. Chromosome types were identified according to Chaikla et al. (2011) as metacentric ( $\mathrm{m}, \mathrm{CI}=0.500-0.599)$, submetacentric (sm, CI $=0.600-0.699)$, subacrocentric (sa, CI =0.7000.799), acrocentric ( $\mathrm{a}, \mathrm{CI}=0.800-0.899)$, or telocentric $(\mathrm{t}, \mathrm{CI}=0.900-1.000)$.

\section{RESULTS}

\section{Chromosome number}

The results of chromosome counts are shown in Table 1. All 97 of the Hippeastrum accessions in this collection have a basic chromosome number $\mathrm{x}=11$. All are euploid with ploidy levels varying from diploid to tetra- ploid. Most Hippeastrum accessions in this collection were found to be diploid with a somatic chromosome number $2 n=2 \mathrm{x}=22$ (62 accessions, or $63.9 \%$ of total studied accessions). Three of the 97 (3.1\%) accessions collected are triploids $(2 n=3 \mathrm{x}=33)$. There are 32 (33\%) tetraploid accessions with a chromosome number $2 n=4 \mathrm{x}=44$.

This collection shows diversity in several morphological characteristics, particularly in flower size and color. Based on their morphological characteristics, these three Hippeastrum species from Vietnam have previously been classified in Hippeastrum collections as $H$. $\mathrm{x}$ 'Johnsonii', H. puniceum, and H. reticulatum var. striatifolia Herb. (Table 2). In order to examine the karyotypes and phylogenesis of these three species, karyotyping was performed using three individual accessions (H141, H142, H128, further defined below) to represent these three species.

Flower characteristics of $\boldsymbol{H} . \mathbf{x}$ 'Johnsonii', $\boldsymbol{H}$. puniceum, and $H$. reticulatum var. striatifolia Herb.

In Vietnam, local Hippeastrum cultivars have usually been traditionally named base on their flower color. Accessions that belong to the species H. x 'Johnsonii' and $H$. puniceum that have become naturalized throughout Vietnam are named "wild red" (Do dai in Vietnamese) and "wild orange" (Cam dai in Vietnamese), respectively. The H. x 'Johnsonii' accession H141 was collected from Hanoi. H. x 'Johnsonii' is known by its scarlet red flower with short white stripes. This accession has flowers $10.8 \mathrm{~cm}$ in diameter, which are smaller than those of the other two species in the present study. The $H$. puniceum accession H142 was collected from Soctrang (Southern Vietnam) and has orange flowers $12.3 \mathrm{~cm}$ in diameter, which are larger than those of the other two species in the present study. The $H$. reticulatum var.

Table 1. Chromosome number of Hippeastrum accessions in Vietnam

\begin{tabular}{ccc}
\hline $\begin{array}{c}\text { Chromosome } \\
\text { number }\end{array}$ & $\begin{array}{c}\text { Number of } \\
\text { accessions }\end{array}$ & $\begin{array}{c}\text { Percentage of total } \\
\text { accessions (\%) }\end{array}$ \\
\hline $2 n=2 \mathrm{x}=22$ & 62 & 63.9 \\
$2 n=3 \mathrm{x}=33$ & 3 & 3.1 \\
$2 n=4 \mathrm{x}=44$ & 32 & 33.0 \\
\hline Total & 97 & 100.0 \\
\hline
\end{tabular}

Table 2. Location of collection and flower characteristics of three typical diploid Hippeastrum species

\begin{tabular}{|c|c|c|c|c|c|}
\hline Species & Accession & $\begin{array}{l}\text { Vietnamese } \\
\text { name }\end{array}$ & $\begin{array}{c}\text { Locality } \\
\text { (District, Province) }\end{array}$ & $\begin{array}{l}\text { Flower diameter } \\
(\mathrm{cm})^{*}\end{array}$ & Flower color \\
\hline H. x 'Johnsonii' & H141 & Đỏ dại & Gialam, Hanoi & $10.8 \pm 0.2$ & Scarlet red with short white stripes \\
\hline H. puniceum & H142 & Cam dại & Trande, Soctrang & $12.3 \pm 0.7$ & Orange \\
\hline $\begin{array}{l}\text { H. reticulatum var. } \\
\text { striatifolia Herb. }\end{array}$ & H128 & Hông sọc & Dongla, Hanoi & $11.5 \pm 1.0$ & Pale pink with netted veins \\
\hline
\end{tabular}

* The number of flowers measured: $\mathrm{n}=10$. 
striatifolia Herb. accession H128 (from Northern Vietnam) has pale pink, $11.5 \mathrm{~cm}$ flowers with netted veins. This variety is named Hong soc in Vietnamese because of its pink flower color.

Karyotypes of $\boldsymbol{H}$. x 'Johnsonii', H. puniceum, and $H$. reticulatum var. striatifolia Herb

The results presented in Table 3 and Fig. 1 show the variation in chromosome size and chromosome arm ratio between individual plants of these three species. Among these three species, the chromosomes of $H . x$ 'Johnsonii' (accession H141) were $126.6 \mu \mathrm{m}$ in total length, while those of $H$. reticulatum var. striatifolia Herb. (accession H128) were $63.1 \mu \mathrm{m}$ in total length. The chromosomes of pair I of $H$. x 'Johnsonii' were $8.1 \mu \mathrm{m}$ in length, while those of $H$. puniceum were $6.9 \mu \mathrm{m}$, and those of $H$. reticulatum var. striatifolia Herb. were only $4.2 \mu \mathrm{m}$ in length. The differences in the lengths of the 10 remaining chromosome pairs of these three species were proportionally similar. The lengths of all 11 of the chromosome pairs of $H$. reticulatum var. striatifolia Herb. were approximately half those of their corresponding chromosome pairs in H. x 'Johnsonii'. Except for pairs V and VI, nine chromosome pairs of $H$. puniceum are of average length in comparison with the others. The chromosome arm ratios also differ among these three species. The chromosome arm ratios of chromosome pairs I, III, and X in these three species are nearly the same. The chromosome arm ratios of the eight remaining chromosome pairs in these three species also differ. All of the three species in the present study have unequal chromosome pairs. However, the number and order of unequal pairs differ between the three species. Chromosome pair II exhibits unequal chromosome pair length in $H$. x 'Johnsonii'. The two chromosomes of this pair clearly differ in length (8.1 $\mu \mathrm{m}$ and $6.9 \mu \mathrm{m})$, but do not differ in chromosome arm ratio (2.3 and 2.4). There are two unequal chromosome pairs, II and VIII, in H. puniceum. The two chromosomes of these two pairs differ in both total length and chromosome arm ratio. Three unequal chromosome pairs, IV, VIII, and XI, were observed in $H$. reticulatum var. striatifolia Herb. The two chromosomes in pair IV differ in length, but are similar in chromosome arm ratio. The two chromosomes of pair VIII differ in both length and chromosome arm ratio. Meanwhile, two chromosomes of pair XI are similar in length but different in chromosome arm ratio.

\section{Karyotype formulas of $H$. $\mathbf{x}$ 'Johnsonii', $H$. puniceum, and $H$. reticulatum var. striatifolia Herb.}

As shown in the Fig. 1, three different chromosome types corresponding to groups A (chromosomes with the shortest short arm), B (chromosomes with a longer short arm), or C (chromosomes that are approximately isobrachial) can be observed in the chromosome complements of $H$. x 'Johnsonii', $H$. puniceum and $H$. reticulatum var. striatifolia Herb. To distinguish the karyotypes of these species, chromosome lengths and centromeric indices were used to define the karyotype formula of each species (Table 4). Accession H141 (H. x 'Johnsonii' species) bears four pairs of subacrocentric chromosomes

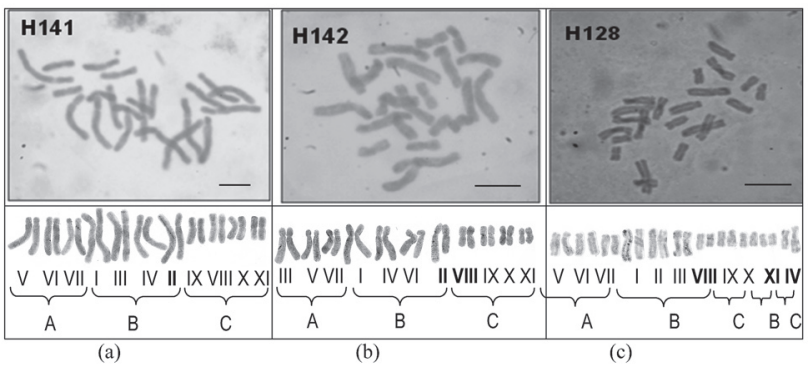

Fig. 1. Mitotic metaphase chromosomes and karyotype of $H$. x 'Johnsonii' (a), H. puniceum (b), and H. reticulatum (c). Roman numerals (I - XI): chromosome pair number. Bold Roman numeral: unequal pair of chromosomes. A: group of chromosomes with the shortest short arm; B: group of chromosomes with a longer short arm; C: group of approximately isobrachial chromosomes. Scale bar: $5 \mu \mathrm{m}$.

Table 3. Chromosome size of three typical diploid Hippeastrum species

\begin{tabular}{|c|c|c|c|c|c|c|c|c|c|c|c|c|c|}
\hline \multirow{2}{*}{$\begin{array}{l}\text { Accession - } \\
\text { Species }\end{array}$} & \multirow{2}{*}{$\begin{array}{l}\text { Chromosome } \\
\text { size }\end{array}$} & \multicolumn{11}{|c|}{ Chromosome pair number } & \multirow{2}{*}{$\begin{array}{c}\text { Total } \\
\text { chromosome } \\
\text { length }(\mu \mathrm{m})\end{array}$} \\
\hline & & I & II & III & IV & $\mathrm{V}$ & $\mathrm{VI}$ & VII & VIII & IX & $\mathrm{X}$ & XI & \\
\hline \multirow{2}{*}{$\begin{array}{c}\text { H141 } \\
\text { H. x 'Johnsonii' }\end{array}$} & $\begin{array}{l}\text { Chromosome } \\
\text { length }(\mu \mathrm{m})\end{array}$ & 8.1 & $\begin{array}{c}8.1 \\
(6.9)^{*}\end{array}$ & 7.5 & 7.2 & 5.6 & 5.6 & 5.3 & 4.4 & 4.2 & 4.1 & 3.8 & \multirow[t]{2}{*}{126.6} \\
\hline & $\begin{array}{l}\text { Chromosome } \\
\text { arm ratio }\end{array}$ & 2.4 & $\begin{array}{c}2.3 \\
(2.4)\end{array}$ & 2.5 & 2.3 & 5.5 & 4.7 & 6.0 & 1.1 & 1.8 & 1.0 & 1.0 & \\
\hline \multirow{2}{*}{$\begin{array}{c}\mathrm{H} 142 \\
\text { H. puniceum }\end{array}$} & $\begin{array}{l}\text { Chromosome } \\
\text { length ( } \mu \mathrm{m})\end{array}$ & 6.9 & $\begin{array}{c}6.6 \\
(4.9)^{*}\end{array}$ & 6.3 & 6.1 & 6.1 & 5.6 & 4.7 & $\begin{array}{c}3.7 \\
(3.4)^{*}\end{array}$ & 3.4 & 3.0 & 2.4 & \multirow[t]{2}{*}{107.9} \\
\hline & $\begin{array}{l}\text { Chromosome } \\
\text { arm ratio }\end{array}$ & 2.4 & $\begin{array}{c}2.5 \\
(1.7)\end{array}$ & 2.5 & 2.7 & 3.3 & 4.2 & 3.0 & $\begin{array}{c}1.4 \\
(1.0)^{*}\end{array}$ & 1.0 & 1.0 & 1.0 & \\
\hline $\begin{array}{c}\mathrm{H} 128 \\
\text { H. reticulatum } \\
\text { var }\end{array}$ & $\begin{array}{l}\text { Chromosome } \\
\text { length }(\mu \mathrm{m})\end{array}$ & 4.2 & 3.8 & 3.4 & $\begin{array}{c}3.4 \\
(2.6)^{*}\end{array}$ & 3.3 & 3.0 & 2.7 & $\begin{array}{c}2.4 \\
(1.9)^{*}\end{array}$ & 2.3 & 2.0 & $\begin{array}{c}1.7 \\
(1.7)^{*}\end{array}$ & \multirow[t]{2}{*}{63.1} \\
\hline $\begin{array}{c}\text { striatifolia } \\
\text { Herb. }\end{array}$ & $\begin{array}{l}\text { Chromosome } \\
\text { arm ratio }\end{array}$ & 2.3 & 2.2 & 2.4 & $\begin{array}{c}1.0 \\
(1.0)\end{array}$ & 3.8 & 3.6 & 5.7 & $\begin{array}{c}2.3 \\
(1.8)^{*}\end{array}$ & 1.0 & 1.0 & $\begin{array}{c}1.5 \\
(1.0)^{*}\end{array}$ & \\
\hline
\end{tabular}

* The values given in parentheses are of the smaller chromosomes in unequal pairs of chromosomes. 
Table 4. Centromeric index of three typical diploid Hippeastrum species

\begin{tabular}{|c|c|c|c|c|c|c|c|c|c|c|c|}
\hline \multirow{2}{*}{$\begin{array}{l}\text { Accession - } \\
\text { Species }\end{array}$} & \multicolumn{11}{|c|}{ Chromosome pair number } \\
\hline & I & II & III & IV & $\mathrm{V}$ & $\mathrm{VI}$ & VII & VIII & IX & $\mathrm{X}$ & XI \\
\hline $\begin{array}{c}\text { H141 } \\
H . \mathrm{x} \text { ‘Johnsonii’ }\end{array}$ & 0.706 & $\begin{array}{c}0.700 \\
(0.708)^{*}\end{array}$ & 0.714 & 0.701 & 0.846 & 0.825 & 0.857 & 0.516 & 0.636 & 0.500 & 0.500 \\
\hline Chromosome type & sa & sa & sa & sa & $\mathrm{a}$ & $\mathrm{a}$ & $\mathrm{a}$ & $\mathrm{m}$ & sm & $\mathrm{m}$ & $\mathrm{m}$ \\
\hline $\begin{array}{c}\mathrm{H} 142 \\
\text { H. puniceum }\end{array}$ & 0.706 & $\begin{array}{c}0.714 \\
(0.630)^{*}\end{array}$ & 0.714 & 0.730 & 0.767 & 0.808 & 0.750 & $\begin{array}{c}0.583 \\
(0.500)^{*}\end{array}$ & 0.500 & 0.500 & 0.500 \\
\hline Chromosome type & sa & $\begin{array}{l}\mathrm{sa} \\
\mathrm{sm}\end{array}$ & $\mathrm{sa}$ & $\mathrm{sa}$ & sa & $\mathrm{a}$ & sa & $\mathrm{m}$ & $\mathrm{m}$ & $\mathrm{m}$ & $\mathrm{m}$ \\
\hline $\begin{array}{l}\text { H128 } \\
\text { H. reticulatum var. } \\
\text { striatifolia Herb. }\end{array}$ & 0.697 & 0.688 & 0.706 & $\begin{array}{c}0.500 \\
(0.500)^{*}\end{array}$ & 0.792 & 0.783 & 0.851 & $\begin{array}{c}0.697 \\
(0.643)^{*}\end{array}$ & 0.500 & 0.500 & $\begin{array}{c}0.600 \\
(0.500) *\end{array}$ \\
\hline Chromosome type & $\mathrm{sm}$ & sm & sa & $\mathrm{m}$ & sa & sa & $\mathrm{a}$ & sm & $\mathrm{m}$ & $\mathrm{m}$ & $\begin{array}{l}\mathrm{sm} \\
\mathrm{m}\end{array}$ \\
\hline
\end{tabular}

* The values given in parentheses are the CI for the smaller chromosomes in unequal pairs of chromosomes.

Table 5. Karyotype formulas of three typical diploid Hippeastrum species

\begin{tabular}{|c|c|c|c|c|c|c|c|c|c|}
\hline \multirow{3}{*}{ Species } & \multirow{3}{*}{ Accession } & \multicolumn{8}{|c|}{ Number of chromosomes } \\
\hline & & \multicolumn{4}{|c|}{ Long chromosome (L) } & \multicolumn{4}{|c|}{ Short chromosome (S) } \\
\hline & & a & $\mathrm{sa}$ & $\mathrm{sm}$ & $\mathrm{m}$ & $\mathrm{a}$ & sa & $\mathrm{sm}$ & $\mathrm{m}$ \\
\hline H. x 'Johnsonii' & H141 & 8 & 6 & 0 & 0 & 0 & 0 & 2 & 6 \\
\hline H. puniceum & H142 & 2 & 11 & 1 & 0 & 0 & 0 & 0 & 8 \\
\hline $\begin{array}{l}\text { H. reticulatum var. } \\
\text { striatifolia } \text { Herb. }\end{array}$ & H128 & 2 & 6 & 4 & 2 & 0 & 0 & 3 & 5 \\
\hline
\end{tabular}

(pairs I, II, III, and IV), three pairs of acrocentric chromosomes (pairs V, VI, and VII), one pair of submetacentric chromosomes (pair IX), and three pairs of metacentric chromosomes (pairs VIII, X, and XI). Five pairs of subacrocentric chromosomes (pairs I, III, IV, V, and VII), four pairs of metacentric chromosomes (pairs VIII, IX, X, and $\mathrm{XI}$ ), and one pair of acrocentric chromosomes (pair VI) were found in the chromosome complement of accession H142 (H. puniceum). The longer of the unequal chromosomes in chromosome pair II in accession H142 is subacrocentric, while the shorter chromosome is submetacentric. Three pairs of subacrocentric chromosomes (pairs III, V, and VI), three pairs of metacentric chromosomes (pairs IV, IX, and X), three pairs of submetacentric chromosomes (pairs I, II, and VIII), and one pair of acrocentric chromosomes (pair VII) were observed in the chromosome complement of accession H128 (H. reticulatum var. striatifolia Herb.). The smallest unequal pair of chromosomes (pair XI) of this accession is comprised of one submetacentric and one metacentric chromosome.

The results shown in Tables 4 and 5 indicate that karyotype formulas of these three accessions from different species are differ from each other. The karyotype formulas of accessions H141, H142 and H128 are 8L + $6 \mathrm{~L}_{\mathrm{sa}}+2 \mathrm{~S}_{\mathrm{sm}}+6 \mathrm{~S}_{\mathrm{m}}, 2 \mathrm{~L}_{\mathrm{a}}+11 \mathrm{LS}_{\mathrm{a}}+1 \mathrm{~L}_{\mathrm{sm}}+8 \mathrm{~S}_{\mathrm{m}}$, and $2 \mathrm{~L}_{\mathrm{a}}+$ $6 \mathrm{~L}_{\mathrm{sa}}+4 \mathrm{~L}_{\mathrm{sm}}+2 \mathrm{~L}_{\mathrm{m}}+3 \mathrm{~S}_{\mathrm{sm}}+5 \mathrm{~S}_{\mathrm{m}}$, respectively.

\section{DISCUSSION}

Many studies have confirmed that most Hippeastrum species have a basic chromosome number of $x=11$. The results of the present study agree with this finding. However, some species with basic chromosome numbers of $\mathrm{x}=10$ for $H$. blumenavia (Arroyo, 1982), or $\mathrm{x}=12$ for $H$. iguazuanum (Williams and Dudley, 1984) have been discovered. However, in our collection no accession had a basic chromosome number different from $\mathrm{x}=$ 11. Aneuploidy has also previously been discovered in some Hippeastrum species (Mookerjea, 1955; Arroyo, 1982), but has not been observed in the present collection. Several authors have also previously reported variation in ploidy levels among Hippeastrum species. For example, diploids $(2 n=2 \mathrm{x}=22)$, triploids $(3 \mathrm{x}=33)$, tetraploids $(4 \mathrm{x}=44)$, pentaploids $(5 \mathrm{x}=55)$, and hexaploids $(6 \mathrm{x}=66)$ have been identified previously and occur in most of the Hippeastrum species studied (Arroyo, 1982; Naranjo and Poggio, 1988; Brandham and Bhandol, 1997; Poggio et al., 2014). We have identified only diploids, triploids, and tetraploids in our Hippeastrum collection in Vietnam. Similarly, most other Hippeastrum accessions from Vietnam are diploid or tetraploid, and there are very few triploid accessions. The H. puniceum plant in our collection was found to be diploid, although other examples of this species with different ploidy levels have been identified (Poggio et al., 2014).

The chromosome lengths of two diploid Hippeastrum species and one cultivar described in the present paper differ from each other as well as from those of other Hippeastrum species studied previously. Brandham and 
Bhandol (1997) reported that the total chromosome length of diploid genomes varied from $126.1 \mu \mathrm{m}$ to 200.4 $\mu \mathrm{m}$ among six different Hippeastrum species (H. aulicum, H. cybister, H. forgetii Worsley, H. pardinum, $H$. puniceum, and $H$. reginae). The total chromosome length of $H$. parodii was measured as $158.5 \mu \mathrm{m}$ (Naranjo and Poggio, 1988). The three diploid accessions in the present study have shorter chromosomes relative to those other species. In particular, accession H128 (H. reticulatum var. striatifolia Herb.) has very short chromosomes that are $63.1 \mu \mathrm{m}$ in total chromosome length. Brandham and Bhandol (1997) hypothesized that, just as for Aloe species studied by Brandham (1983), the more primitive Hippeastrum species might have smaller genomes. By similar reasoning, we speculate that $H$. reticulatum could be the most primitive species among the species we have examined.

Karyotypic differences between the three diploid Hippeastrum species in this study were clearly observed. As for other Hippeastrum species, diploid genomes of these species are also comprised of 14 long chromosomes and eight short chromosomes; however, the karyotype formulas of these species differ from each other as well as from those of other species published previously. Shafiq and Vahidy (1998) observed a basic karyotype of two metacentric, two submetacentric, four subacrocentric, and three acrocentric chromosomes in their analysis of Hippeastrum vittatum plants. Five of six Hippeastrum species studied by Brandham and Bhandol (1997) had 14 long acrocentric and eight short metacentric chromosomes in their diploid karyotypes, while other species (H. reginae) had 12 long acrocentric, one long metacentric, and eight short metacentric chromosomes. These authors did not define subacrocentric and submetacentric chromosomes in their analyses. Hippeastrum parodii was found to have basic karyotype of three subtelocentric (or subacrocentric), four submetacentric, and four metacentric chromosomes (Naranjo and Poggio, 1988). The karyotypic dissimilarities observed have previously been attributed to possible amphiplasty, pericentric inversions, or unequal reciprocal translocations (Shafiq and Vahidy, 1998). Thus, karyotype formulas are quite specific to different plants and species. The karyotype formula of diploid H. puniceum in our study differed clearly from those of triploid and hexaploid $H$. puniceum studied by Poggio et al. (2014). We found unequal or mismatched chromosome pairs in our study in numbers varying from one in $H . \mathrm{x}$ 'Johnsonii' to three in $H$. reticulatum Herb. var. striatifolia Herb. Mismatches were observed in $H$. reticulatum var. striatifolia Herb. chromosome pairs II, IV, VIII, and XI. Shafiq and Vahidy (1998) found mismatches for two chromosome pairs (VII and XI) in diploid H. vittatum and in two chromosome pairs (IV and XI) in tetraploid H. vittatum. The mismatched chromosomes in their study were assumed to provide evidence of extensive hybridization during the evolution of the species. By similar reasoning, we assume that the Hippeastrum accessions in the present study are probably natural hybrids.

\section{CONCLUSION}

The Hippeastrum germplasm collection in Vietnam includes diploid, triploid, and tetraploid accessions. A large proportion of the entire collection consists of diploids. The differences in chromosome lengths, long arm to short arm ratios, centromere positions, and chromosome types among the three plants observed from $H$. x 'Johnsonii', H. puniceum, and H. reticulatum var. striatifolia Herb. revealed the variation in their karyotypes. These species carry from one to three unequal pair(s) of chromosomes in their chromosome complements. The results of this study will be useful for the identification and classification the Hippeastrum species for breeding purposes.

\section{ACKNOWLEDGMENTS}

This research was financed by the National Foundation for Science and Technology Development (NAFOSTED), the Ministry of Science and Technology of Vietnam (Reference code: 106.11-2010.46), which we would like to thank for supporting this research.

\section{REFERENCES}

Arroyo, S. 1982 The chromosomes of Hippeastrum, Amaryllis and Phycella (Amaryllidaceae). Kew Bulletin, 37(2): 211216

Baldwin, Jr. J. T. and B. M. Speese 1947 Hippeastrum solandriflorum: Its Chromosomes. Bulletin of the Torrey Botanical Club, 74(3): 250-254

Barnhoorn, F. 1995 Growing bulbs in Southern Africa. Southern Book Publishers (Pty) Ltd, Halfway House, South Africa

Brandham, P. E. and P. S. Bhandol 1997 Chromosomal relationships between the genera Amaryllis and Hippeastrum (Amaryllidaceae). Kew Bulletin, 52(4): 973-980

Chaikla, P., C. Suwanthada and C. Trisonthi 2011 Morphological, anatomic and karyotypic characteristics of Peliosanthes teta Andrew. African Journal of Agricultural Research, 6(32): 6698-6705

Guha, S. 1979 Cytological studies in the genus Amaryllis. Bull. Bot. Surv. India, 21:18-21

Mookerjea, A. 1955 Cytology of Amaryllids as an aid to the understanding of evolution. Caryologia, 7: 1-71

Naranjo, C. A. and L. Poggio 1988 A Comparison of Karyotype, Ag-NOR Bands and DNA Content in Amaryllis and Hippeastrum (Amaryllidaceae). Kew Bulletin, 43(2): 317 325

Okubo, H. 1993 Hippeastrum (Amaryllis). In "The Physiology of Flower Bulbs", ed. by A. D. Hertogh and M. L. Nard. Elsevier, Amsterdam (The Netherlands) pp. 321-324

Phuong P. T. M., S. Isshiki and I. Miyajima 2014 Genetic variation of Hippeastrum accessions in Vietnam. J. Fac. Agr., Kyushu Univ., 59(2): 235-241

Poggio, L., M. F. Realini, M. F. Fourastié, A. M. García, and G. E. González 2014 Genome downsizing and karyotype constancy in diploid and polyploid congeners: a model of genome size variation. The open-access journal for plant sciences AoB PLANTS 6: plu029; doi:10.1093/aobpla/plu029

Shafiq, F. A. and A. A. Vahidy 1998 Chromosomal heteromorphy in the karyotypes of three local cultivars of Hippeastrum vittatum (Amaryllidaceae). Pakistan Journal of Biological Sciences 1(1): 1-4

Williams, M. and T. R. Dudley 1984 Chromosome Count for Hippeastrum iguazuanum. Taxon, 33(2): 271-275 